\title{
Cell Cycle and Cancer: Genetic Analysis of the Role of Cyclin-dependent Kinases
}

\author{
M. Barbacid, S. Ortega, R. Sotillo, J. Odajima, A. Martín, D. Santamaría, \\ P. Dubus, * and M. Malumbres \\ Molecular Oncology Program, Centro Nacional de Investigaciones Oncológicas (CNIO), Melchor Fernández \\ Almagro 3, 28029 Madrid, Spain; *EA2406 University of Bordeaux 2, F-33076 Bordeaux, France
}

\begin{abstract}
Most human tumors harbor mutations that misregulate the early phases of the cell cycle. Here, we summarize genetic evidence, mostly obtained in our laboratory using strains of gene-targeted mice, that provides direct experimental support for a role of Cdk4 in tumor development. Moreover, these genetic studies challenge some well-established concepts regarding the role of Cdks during the early phases of the cell cycle. For instance, they have illustrated that Cdk4 and Cdk6 are not essential for cell division during embryonic development except in the hematopoietic system. More surprisingly, mice lacking Cdk2 survive for over 2 years without detectable abnormalities except in their germ cells, indicating that Cdk2 is essential for meiosis but dispensable for the normal mitotic cell cycle. Cdk2 is also dispensable for cell cycle inhibition and tumor suppression by the Cip/Kip inhibitors, $\mathrm{p} 21^{\mathrm{Cip} 1}$ and $\mathrm{p} 27^{\mathrm{Kip} 1}$. These observations have important implications not only to understand cell cycle regulation, but also to validate Cdks as potential targets for the development of therapeutic strategies to block proliferation of tumor cells.
\end{abstract}

To ensure proper progression through the cell cycle, cells have developed a series of checkpoints that prevent them from entering into a new phase of the cycle until they have successfully completed the previous one. Recently divided or quiescent cells also must pass certain checkpoints before they enter a new cycle. For instance, these cells must determine whether they have all the necessary nutrients to carry out cell division. They also need to sense that they have reached proper homeostatic cell size, otherwise they will decrease (or increase) in size with each round of division. Metazoans must also control the number of cells in every organ, a parameter that, coupled with cell size, ultimately determines the size of every individual. In addition, cells must control the amount of mitogenic information required to enter the cycle (for review, see Malumbres and Barbacid 2001). Too stringent requirements would prevent cell proliferation at critical times such as during wound healing or to fight an infection. On the other hand, overly relaxed controls would lead to unscheduled proliferation and possibly neoplastic growth.

The mammalian cell cycle (see Fig. 1) is thought to be driven by heterodimeric kinases composed of a catalytic subunit known as cyclin-dependent kinase $(\mathrm{Cdk})$ and a regulatory subunit, designated as cyclin. Two of these Cdks, Cdk4 and Cdk6, bind to and are activated by the Dtype family of cyclins, D1, D2, and D3 (for review, see Sherr and Roberts 1999). The D-type cyclins are critical integrators of mitogenic signaling since their synthesis is one of the main endpoints of the Ras/Raf/MAPK signaling pathway. Interestingly, mouse embryonic fibroblasts that lack the three D-type cyclins can proliferate, indicating that these molecules are not strictly necessary for progression through $\mathrm{G}_{1}$ (Kozar et al. 2004; see below). Whether this activity is mediated by other cyclins, or by alternative mechanisms, remains to be resolved.

The primary role of the D-type cyclin/Cdk4 or Cdk6 complexes is to phosphorylate members of the retinoblastoma $(\mathrm{Rb})$ protein family, $\mathrm{pRb}, \mathrm{p} 107$, and $\mathrm{p} 130$. The $\mathrm{Rb}$ proteins are tumor suppressors that in their active, nonphosphorylated state prevent expression of genes necessary for DNA replication (S phase of the cell cycle) and mitosis (M phase). Phosphorylation of $\mathrm{pRb}$ by D-type cyclin/Cdk4 or Cdk6 complexes results in its partial inactivation, which, in turn, allows expression of a limited number of transcriptional targets needed to drive cells through the $\mathrm{G}_{1}$ phase of the cell cycle (for review, see Co-

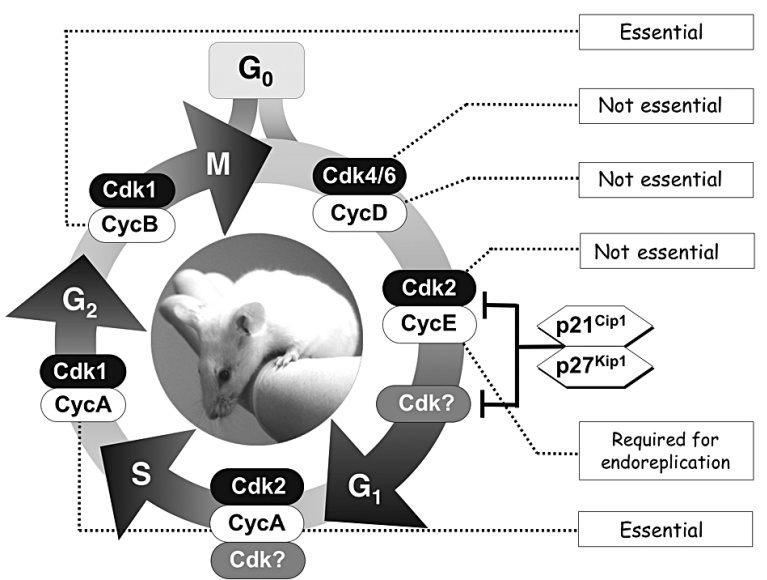

Figure 1. Schematic representation of the mammalian cell cycle. The distinct phases of the mammalian cell cycle, including quiescence $\left(\mathrm{G}_{0}\right)$, Gap $1\left(\mathrm{G}_{1}\right)$, DNA synthesis $(\mathrm{S})$, Gap2 $\left(\mathrm{G}_{2}\right)$, and mitosis $(\mathrm{M})$ are indicated. Those $\mathrm{Cdk} /$ cyclin complexes thought to drive each of these phases are also indicated. Cdk? represents a putative Cdk responsible for mediating the inhibitory activity of the Cip/Kip proteins in $\mathrm{G}_{1}$ and/or driving DNA synthesis in the absence of $\mathrm{Cdk} 2$. Boxes on the right side indicate whether each of these molecules is essential for cell cycle progression based on genetic studies using gene-targeted mice. For more details see Table 1 . 
Table 1. Genetic Analysis of Mammalian Cell Cycle Cdks

\begin{tabular}{|c|c|c|c|c|c|}
\hline Cdk & Alteration & Viability & Phenotype in vivo & Phenotype in vitro & References \\
\hline Cdk4 & $\begin{array}{l}\text { R42C mutant } \\
\text { insensitive to } \\
\text { INK4 inhibitors }\end{array}$ & viable & $\begin{array}{l}\text { epithelial and mesenchymal } \\
\text { tumors with complete } \\
\text { penetrance after } 14-18 \\
\text { months }\end{array}$ & $\begin{array}{l}\text { faster cell cycles and no } \\
\text { "culture crisis"; increased } \\
\text { susceptibility to } \\
\text { transformation by Ras } \\
\text { oncogenes }\end{array}$ & Sotillo et al. $(2001 \mathrm{a}, \mathrm{b})$ \\
\hline Cdk4 & null mutation & viable & $\begin{array}{l}\text { lack of proliferation of post- } \\
\text { natal pancreatic } \beta \text {-cells and } \\
\text { pituitary lactotrophs; small } \\
\text { size }\end{array}$ & $\begin{array}{l}\text { decreased susceptibility to } \\
\text { immortalization or trans- } \\
\text { formation by oncogenes }\end{array}$ & $\begin{array}{l}\text { Rane et al. (1999); } \\
\text { Tsutsui et al. (1999); } \\
\text { Moons et al. (2002); } \\
\text { Martín et al. (2003) }\end{array}$ \\
\hline Cdk6 & null mutation & viable & $\begin{array}{l}\text { defective erythroid lineage } \\
\text { development }\end{array}$ & $\begin{array}{l}\text { no phenotype in MEFs but } \\
\text { delayed proliferation of } \\
\text { lymphoid cells }\end{array}$ & Malumbres et al. (2004) \\
\hline $\begin{array}{l}\text { Cdk4 and } \\
\text { Cdk6 }\end{array}$ & $\begin{array}{l}\text { double null } \\
\text { mutant }\end{array}$ & $\begin{array}{l}\text { late - } \\
\text { embryonic } \\
\text { lethality }\end{array}$ & $\begin{array}{l}\text { limited proliferation of } \\
\text { committed hematopoietic } \\
\text { precursors, especially those } \\
\text { of erythroid origin }\end{array}$ & $\begin{array}{l}\text { delayed cell cycles and } \\
\text { decreased pRb phosphory- } \\
\text { lation; cells respond to } \\
\text { mitogenic stimuli and } \\
\text { become immortal upon } \\
\text { passage }\end{array}$ & Malumbres et al. (2004) \\
\hline $\mathrm{Cdk} 2$ & null mutation & viable & $\begin{array}{l}\text { male and female sterility due } \\
\text { to meiotic defects; no defects } \\
\text { in mitotic cells }\end{array}$ & $\begin{array}{l}\text { Early senescence in MEFs in } \\
\text { culture; no major cell cycle } \\
\text { defects }\end{array}$ & Ortega et al. (2003) \\
\hline $\mathrm{Cdk} 2$ & $\begin{array}{l}\text { conditional null } \\
\text { mutation }\end{array}$ & viable & no phenotype observed & $\begin{array}{l}\text { no defects in cell proliferation } \\
\text { after ablation }\end{array}$ & $\begin{array}{l}\text { our unpublished } \\
\text { observations }\end{array}$ \\
\hline $\begin{array}{l}\text { Cdk2 and } \\
\text { Cdk6 }\end{array}$ & $\begin{array}{l}\text { double null } \\
\text { mutant }\end{array}$ & viable & $\begin{array}{l}\text { phenotype identical to Cdk2 } \\
\text { and Cdk6 single mutants }\end{array}$ & $\begin{array}{l}\text { phenotype identical to Cdk2 } \\
\text { and Cdk6 single mutants; } \\
\text { no synergism }\end{array}$ & Malumbres et al. (2004) \\
\hline Cdk3 & $\begin{array}{l}\text { premature stop } \\
\text { codon }\end{array}$ & viable & $\begin{array}{l}\text { normal; most laboratory } \\
\text { strains carry this mutation }\end{array}$ & $\begin{array}{l}\text { normal; mutation present in } \\
\text { "wild type" MEFs }\end{array}$ & Ye et al. (2001) \\
\hline
\end{tabular}

For related information on mice defective in the corresponding cyclins, see Ciemerych and Sicinski (2005).

brinik 2005). Some of these targets include the E-type cyclins (E1 and E2), whose primary role is to activate Cdk2. Active E-type cyclin/Cdk2 complexes further phosphorylate $\mathrm{pRb}$, leading to a wave of transcriptional activity essential to proceed through the $\mathrm{G}_{1} / \mathrm{S}$ transition.

$\mathrm{Cdk}$ activity can be negatively regulated by $\mathrm{Cdk}$ inhibitors (CKI). CKIs come in two flavors. The four-member INK4 family $\left(\mathrm{p} 16^{\mathrm{INK} 4 \mathrm{a}}, \mathrm{p} 15^{\mathrm{INK} 4 \mathrm{~b}}, \mathrm{p} 18^{\mathrm{INK} 4 \mathrm{c}}\right.$, and $\mathrm{p} 19^{\mathrm{INK} 4 \mathrm{~d}}$ ) exerts its inhibitory activity by binding to the $\mathrm{Cdk} 4$ and Cdk6 kinases and preventing their association with D-type cyclins (Sherr and Roberts 1999). Although INK4 proteins are biochemically indistinguishable from each other in vitro, they are expressed at different times during embryonic and postnatal development. Moreover, generation of gene-targeted mice deficient for each of these proteins has revealed significant functional differences (for review, see Ortega et al. 2002). The three members of the Cip/Kip family, p2 $1^{\text {Cip1 }}$, p $27^{\text {Kip1 }}$, and p $57^{\text {Kip2 }}$, form heterotrimeric complexes with all the $\mathrm{G}_{1} / \mathrm{S}$ Cdks and their cognate cyclins (Sherr and Roberts 1999). However, in stoichiometric amounts, they preferentially inhibit the kinase activity of $\mathrm{Cdk} 2 /$ cyclin E complexes (see below).

\section{CELL CYCLE AND CANCER}

Molecular analysis of human tumors has revealed frequent mutations and epigenetic changes within cell cycle regulators (Malumbres and Barbacid 2001). Most of these molecular alterations occur in $\mathrm{G}_{1}$ regulators, thus underscoring the importance of maintaining proper control of cell cycle commitment to prevent human cancer. They include overexpression of cyclins (mainly cyclins D1 and E1) and Cdks (mainly Cdk4 and Cdk6) as well as loss of CKI expression (mainly $\mathrm{p} 16^{\mathrm{INK} 4 \mathrm{a}}, \mathrm{p} 15^{\mathrm{INK} 4 \mathrm{~b}}$, and $\mathrm{p} 27^{\mathrm{Kip} 1}$ ) and of $\mathrm{pRb}$. Moreover, Cdk4 has been found mutated in familial melanoma. Although most of these tumor-associated alterations result from DNA mutations, it is becoming increasingly evident that epigenetic silencing of certain promoters (e.g., p16 ${ }^{\mathrm{INK} 4 \mathrm{a}}, \mathrm{p} 15^{\mathrm{INK} 4 \mathrm{~b}}$, or $\mathrm{pRb}$ ) also plays a significant role in tumor development (for review, see Esteller 2005).

Direct genetic or epigenetic alteration of $\mathrm{Cdk} 2$ has been rarely described. Yet, expression of some of its most direct regulators, $\mathrm{p} 27^{\mathrm{Kip} 1}$ and cyclin $\mathrm{E} 1$, is frequently altered in human tumors, changes that often correlate with poor prognosis (for review, see Yamasaki and Pagano 2004). Within the Rb protein family, loss or inactivation of $\mathrm{pRb}$ is a rather frequent event in human tumors. However, p130 is less frequently lost, and p107 inactivation has not been reported (for review, see Paggi and Giordano 2001). These observations suggest that p107 and p130 may play a primary role in promoting differentiation rather than proliferation, a concept supported by results obtained with gene-targeted mice (for review, see Classon and Harlow 2002). Finally, mutations in the E2F family of transcription factors have not been observed in human tumors. 


\section{WIDESPREAD TUMOR INDUCTION IN MICE EXPRESSING A MISREGULATED Cdk4 KINASE}

Most human tumors have genetic and/or epigenetic alterations in the cyclin D-INK4-Cdk4/6-pRb pathway. As indicated above, a miscoding mutation (replacement of Arg-24 by Cys) that renders Cdk4 resistant to INK4 inhibitors is associated with the development of human melanoma. To study the effects of such mutation in the regulation of the cell cycle in particular and in tumorigenesis in general, we have engineered knockin mice that carried this mutation within the endogenous mouse $C d k 4$ locus (Rane et al. 1999). $C d k 4^{\mathrm{R} 24 \mathrm{C} / \mathrm{R} 24 \mathrm{C}}$ mice are born at the expected Mendelian ratio, are fertile, and develop normally. However, these mice developed detectable tumors after 8 months and most of them died by 16 months of age (Sotillo et al. 2001a). Necropsy of more than 100 $C d k 4^{\text {R24C/R24C }}$ mice showed a wide spectrum of tumors, including malignancies of mesenchymatous origin $(67 \%$ incidence); epithelial endocrine (55\%); epithelial non-endocrine $(24 \%)$, and, to a lesser extent, hematopoietic malignancies (3\%). Many mice exhibit multiple tumors of independent origin, with an average of almost two tumors per animal. A cohort of 50 mice sacrificed at 14-16 months of age without external signs of disease revealed a similar tumor distribution pattern, except for reduced incidence of sarcomas and pituitary tumors, suggesting that these malignancies are a major cause of death in $C d k 4^{\mathrm{R} 24 \mathrm{C} / \mathrm{R} 24 \mathrm{C}}$ mice. $C d k 4^{+/ \mathrm{R} 24 \mathrm{C}}$ mice also succumbed to the same types of malignancies, although with increased latency (Sotillo et al. 2001a).

Cdk4 misregulation synergizes with mutations in other cancer genes such as p53. Double mutant $C d k 4^{\mathrm{R} 24 \mathrm{C} / \mathrm{R} 24 \mathrm{C}} ; p 53^{-1-}$ mice die before reaching 4 months of age, significantly earlier than their $C d k 4^{+/+} ; p 53^{-/-}$littermates (Sotillo et al. 2001a). These mice display an increased number of sarcomas, mainly hemangiosarcomas and leiomyosarcomas. Moreover, a significant fraction of these double mutant mice (10\%) develop immature teratomas, a tumor not found in any of their single mutant siblings, although a low incidence of teratomas $(<2 \%)$ has been described previously in $p 53^{-/-}$mice. These results suggest that these key regulators exert growth control at different threshold levels in different cell types.

\section{A MUTANT Cdk4R24C KINASE INDUCES INVASIVE MELANOMAS IN MICE}

Interestingly, $C d k 4^{\mathrm{R} 24 \mathrm{C} / \mathrm{R} 24 \mathrm{C}}$ mice do not develop melanomas, the type of tumor induced by this very same mutation in humans. To determine whether these observations were a consequence of intrinsic mechanistic differences between human and rodents or of phenotypic differences, we submitted the skin of these mutant mice to carcinogenic insults. Specifically, $C d k 4^{\mathrm{R} 24 \mathrm{C} / \mathrm{R} 24 \mathrm{C}}$ mice were treated with 7,12-dimethylbenz $[a]$ anthracene (DMBA) followed by repeated exposure to $12-O$-tetradecanoylphorbol-13-acetate (TPA), a treatment known to induce the rapid development of skin papillomas. Unlike wild-type mice, $C d k 4^{\mathrm{R} 24 \mathrm{C} / \mathrm{R} 24 \mathrm{C}}$ animals develop a high number of nevi that rapidly grow in size, leading to the formation of tumors of up to $20 \mathrm{~mm}$ in diameter by 20 weeks (Sotillo et al. 2001b). Alternative treatments with DMBA plus UVB light also result in the development of similar tumors, albeit with reduced efficiency. No melanocytic tumors are observed after single treatments with either DMBA or UVB light alone.

Histological examination of these lesions confirmed the presence of melanomas in $70 \%$ of carcinogen-treated $C d k 4^{\mathrm{R} 24 \mathrm{C} / \mathrm{R} 24 \mathrm{C}}$ mice (Sotillo et al. 2001b). Unlike other models of melanoma, these tumors are highly melanotic, a property that makes them more reminiscent of those observed in humans. Moreover, as observed in human melanomas, the percentage of melanotic cells decreases in advanced malignancies, since active proliferation and melanocyte dedifferentiation often result in decreased production of melanin. In the more advanced melanomas, $C d k 4^{\mathrm{R} 24 \mathrm{C} / \mathrm{R} 24 \mathrm{C}}$ tumors are highly cellular, mainly composed of proliferating atypical melanocytes, frequently spindle-shaped with low or no load of melanin. Mitotic figures and areas of necrosis can be easily found. In these cases, melanocyte proliferation is usually invasive to neighbor tissues with infiltrating margins. The neuroectodermal origin of the melanomas is confirmed by positive immunological staining for the S100 antigen. Molecular analysis of $C d k 4^{\mathrm{R} 24 \mathrm{C} / \mathrm{R} 24 \mathrm{C}}$ melanomas did not reveal either deletion, rearrangement or promoter methylation in p16 ${ }^{I N K 4 a}, p 15^{I N K 4 b}$, or $p 19^{A R F}$ loci (Sotillo et al. 2001b). Although these results are expected for those genes encoding upstream INK4 regulators, the absence of $p 19^{A R F}$ inactivation suggests that alterations in the $\mathrm{p} 53$ pathway are not needed for induction and/or progression of these melanomas.

\section{GENETIC ANALYSIS OF THE ROLE OF Cdks IN VIVO}

Targeting the cell cycle is an attractive strategy to block neoplastic growth, since most human tumors carry molecular alterations in genes that regulate cell cycle commitment. Unfortunately, most cell cycle regulators altered in human cancer, such as loss of p2 $7^{\text {Kip1 }}, \mathrm{p} 16^{\text {Ink4a }}$, or $\mathrm{pRb}$ expression, overexpression of cyclin $\mathrm{D}$ and cyclin E, etc., are not amenable to classic pharmacological approaches. On the other hand, the Cdks, regardless of whether they are mutated or not, are suitable targets for therapeutic intervention. Indeed, kinase inhibition has already been successfully used for therapeutic purposes in many diseases, including cancer (e.g., Gleevec). Yet, our current knowledge of the cell cycle is not sufficient to ensure the development of optimal strategies. For instance, we do not know which Cdk inhibitors will provide the best therapeutic benefit or whether it would be more efficacious to block two or several Cdks at the same time.

To gain further knowledge about the role of individual Cdks in the proliferation of normal and tumor cells, we have embarked on the systematic analysis of each of the four cell cycle Cdks: Cdk1, Cdk2, Cdk4, and Cdk6, at the genetic level using gene-targeted strategies in embryonic stem cells. A fifth Cdk also implicated in the cell cycle 
(Ren and Rollins 2004), Cdk3, is mutated in most strains of laboratory mice (Ye et al. 2001) and will no longer be considered here. Below is a summary of the main results derived from characterizing strains of mice lacking Cdk4, Cdk6, or Cdk2, as well as of double mutant strains lacking $\mathrm{Cdk} 4$ and $\mathrm{Cdk} 6\left(\mathrm{Cdk}^{-1-} ; \mathrm{Cdk}^{-/-}\right), \mathrm{Cdk} 2$ and $\mathrm{Cdk} 6$ $\left.C d k 2^{-1-} ; C d k 6^{--}\right)$, and Cdk2 and its inhibitors p $27^{\mathrm{Kip} 1}$ $\left(C d k 2^{-/-} ; p 27^{\text {Kip1-l-- }}\right)$ and $\mathrm{p} 21^{\mathrm{Cip} 1}\left(\mathrm{Cdk2^{-/- }} ; \mathrm{p} 21^{\mathrm{Cip1-l-}}\right)$.

\section{Cdk4 null MICE}

Ablation of Cdk4 does not have significant consequences for cell proliferation, at least in mouse embryonic fibroblasts (MEFs). Quiescent $C d k 4$ null $\left(C d k 4^{\mathrm{n} / \mathrm{n}}\right) \mathrm{MEFs}$ enter S phase with slightly delayed kinetics but proliferate normally (Rane et al. 1999; Tsutsui et al. 1999). In vivo, $C d k 4^{\mathrm{n} / \mathrm{n}}$ mice are viable, indicating that Cdk4 is not essential for proliferation of most cell types (Rane et al. 1999; Tsutsui et al. 1999). Yet, these mice have limited populations of certain endocrine cell types. For instance, adult $C d k 4^{\mathrm{n} / \mathrm{n}}$ mice become diabetic due to reduced numbers of insulin-producing pancreatic $\beta$-cells (Rane et al. 1999; Tsutsui et al. 1999). Subsequent studies have indicated that $\mathrm{Cdk} 4$ is essential for postnatal proliferation of pancreatic $\beta$-cells but not for their neogenesis from ductal epithelial cells (Martín et al. 2003). Interestingly, Cdk6 expression is basically undetectable in postnatal pancreatic $\beta$-cells, thus providing a possible explanation for their strict dependence on Cdk4 expression.

Cdk4 null mice also have decreased male fertility due to defective spermatogenesis and reduced numbers of Leydig cells (Rane et al. 1999; Tsutsui et al. 1999). Female $C d k 4^{\mathrm{n} / \mathrm{n}}$ mice are completely sterile due to limited prolactin production, a consequence of their reduced numbers of pituitary lactotrophs (Moons et al. 2002; Jirawatnotai et al. 2004). As in the case of pancreatic $\beta$-cells, Cdk4 is essential for postnatal proliferation of the anterior pituitary, but it is not required for embryonal development of the pituitary gland (Moons et al. 2002). Interestingly, siRNA-mediated knockdown of $C d k 4$, but not of $C d k 6$, inhibits GHRH-induced proliferation of GH3 somato/lactotroph cells with restored expression of GHRH receptors, thus suggesting distinct functional roles for these highly related kinases within the same cellular context (Jirawatnotai et al. 2004).

Finally, $C d k 4^{\mathrm{n} / \mathrm{n}}$ mice are considerably smaller than their wild-type littermates (Rane et al. 1999; Tsutsui et al. 1999). This phenotype is not a consequence of the hormonal defects of Cdk4 null animals. $C d k 4^{\mathrm{n} / \mathrm{n}}$;Rip-Cre mice, in which an active Cdk4 kinase is re-expressed in pancreatic $\beta$-cells and in pituitary lactotrophs, are normoglycemic and fully fertile, yet they retain their small-size phenotype (Martín et al. 2003). Since the size of Cdk4 null cells appears to be similar to that of wild-type cells, it is possible that Cdk4 plays a role in controlling homeotic cell numbers, at least in mice.

\section{Cdk6 null MICE}

Mice lacking Cdk6 develop normally and are viable, although hematopoiesis is slightly impaired (Malumbres et al. 2004). This is a somewhat expected result, since Cdk6 is most abundantly expressed in lymphoid organs. In Cdk6-deficient mice, the thymus is reduced in size due to lower cellularity, and its cortical area is atrophic in about one-third of the mutant animals. Their spleens are also reduced in size due to decreased cell density in the red pulp. Whereas in wild-type mice, $70-75 \%$ of all spleen cells belong to the erythroid lineage, these figures decrease to $35-40 \%$ in $C d k 6^{-1-}$ littermates. Similarly, the number of megakaryocytes is severely reduced to less than one-third of those present in wild-type spleens (Malumbres et al. 2004). Cdk6 null mice also exhibit lower numbers of red cells (about 15\%) in peripheral blood. Interestingly, $C d k 6^{-1-}$ mice do not display obvious deficiencies in the bone marrow. In vitro, Cdk6 null lymphocytes, but not $C d k 6^{-1-}$ MEFs, show delayed entry in the cell cycle upon mitogenic stimulation (Malumbres et al. 2004).

\section{LATE EMBRYONIC LETHALITY OF Cdk4;Cdk6 DOUBLE MUTANT MICE}

Mice lacking both cyclin D-dependent kinases, Cdk4 and Cdk6, are not viable. Yet, $C d k 4^{\mathrm{n} / \mathrm{n}} ; C d k 6^{--}$double mutant embryos develop to midgestation with the expected Mendelian frequency, suggesting that they do not have intrinsic cell cycle defects (Malumbres et al. 2004). The percentage of dead embryos increases during late embryonic development. Although some $C d k 4^{\mathrm{n} / \mathrm{n}} ; C d k 6^{-/-}$ pups can make it to term, all of them have been found to be dead at birth. These double null embryos/pups and their corresponding placentas are well formed and do not present significant abnormalities. Moreover, all tissues, except for those of hematopoietic origin, display normal levels of proliferating and apoptotic cells. E14.5 to E18.5 $C d k 4^{\mathrm{n} / \mathrm{n}} ; C d k 6^{-1-}$ embryos have structurally aberrant livers with decreased levels of erythroid precursors. Peripheral blood also reveals a dramatic decrease in the number of red blood cells that display a megaloblastic feature typical of anemia. These findings suggest that $C d k 4^{\mathrm{n} / \mathrm{n}} ; C d k 6^{-1-}$ embryos die during the late stages of embryonic development due to limited proliferation of erythroid progenitors.

The relative numbers of $C d k 4^{\mathrm{n} / \mathrm{n}} ; C d k 6^{-1-}$ hematopoietic stem cells (HSCs) appear to be normal, although their absolute numbers are decreased due to the lower cellularity of the mutant livers (around 15\%). However, the levels of other $C d k 4 / C d k 6$ null lineage-committed progenitors are reduced beyond those levels expected from the decreased cellularity (Malumbres et al. 2004). Accordingly, the numbers of more mature hematopoietic cells, such as monocytes, macrophages, or lymphocytes, are also reduced. Interestingly, the phenotype of $C d k 4^{\mathrm{n} / \mathrm{n}} ; C d k 6^{--}$ double knockout mice is very similar to that observed in mice lacking the three D-type cyclins (Kozar et al. 2004). Yet, D-type cyclin-depleted embryos exhibit a more dramatic reduction of hematopoietic cells. Whether the formation of $\mathrm{Cdk} 2 /$ cyclin $\mathrm{D}$ complexes (see below) contributes to alleviate the requirement for $\mathrm{Cdk} 4$ and $\mathrm{Cdk} 6$ in hematopoietic cells remains to be determined. 


\section{Cdk4 AND Cdk6 DEFECTIVE MEFs}

Early passage $C d k 4^{\mathrm{n} / \mathrm{n}} ; C d k 6^{-1-}$ MEFs proliferate well, albeit at a slower rate than control cells (Malumbres et al. 2004). Moreover, all $\mathrm{Cdk}^{\mathrm{n} / \mathrm{n}} ; \mathrm{Cdk}^{-/-}$double mutant MEFs can immortalize upon continuous passage in culture. These MEFs also proliferate in low serum conditions and respond to mitogenic stimuli induced by addition of EGF and IGF-1. Moreover, they enter S phase upon mitogenic stimulation with normal kinetics, albeit less efficiently than wild-type cells. These observations, taken together, indicate that the D-type cyclin-dependent kinases are not essential either for cell proliferation or for re-entry in the cell cycle, at least in MEFs.

Ablation of Cdk4 and Cdk6 does not affect expression of D-type cyclins. These cyclins, in the absence of their cognate partners, form functional complexes with Cdk2 (Malumbres et al. 2004). Indeed, these Cdk2/cyclin D kinases phosphorylate $\mathrm{pRb}$, at least in vitro. Moreover, $C d k 2$ shRNA significantly decreases the rate of BrdU incorporation in $C d k 4^{\mathrm{n} / \mathrm{n}} ; C d k 6^{-1-}$ MEFs. These observations suggest that in the absence of Cdk4 and Cdk6, Cdk2, in association with D-type cyclins, may help to drive cells through the early phases of the cell cycle. Yet, confirmation of this hypothesis must await genetic scrutiny; for instance, by generating $\mathrm{Cdk} 4 / \mathrm{Cdk} 6 / \mathrm{Cdk} 2$ triple mutant mice.

\section{ABLATION OF THE $C d k 2$ LOCUS REVEALS Cdk2 AS AN ESSENTIAL MEIOTIC KINASE}

$C d k 2^{-/-}$mice are born at the expected Mendelian ratio, indicating that $\mathrm{Cdk} 2$ is not essential for cell proliferation in most, if not all, tissues (Berthet et al. 2003; Ortega et al. 2003). Moreover, these mutant mice do not display gross anatomical or behavioral abnormalities for up to 2 years of life except for severe atrophy in their gonads that results in complete sterility. Spermatogenesis defects in $C d k 2^{-1-}$ male mice become visible at P20, a time when

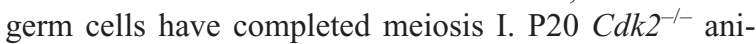
mals do not have round spermatids in the seminiferous tubules, and there is massive apoptosis of spermatocytes (Ortega et al. 2003). Analysis of spermatocytes from adult mice by immunoconfocal microscopy shows leptotene, zygotene, and pachytene stages, but no diplotene or later meiotic stages. Studies using immunohistochemical markers firmly established that the absence of Cdk2 triggers the pachytene checkpoint responsible for the massive apoptosis observed in $C d k 2^{-/-}$spermatocytes (Ortega et al. 2003).

$C d k 2^{-/-}$oocytes develop normally through the leptotene, zygotene, and pachytene stages (E14.5-E18.5). However, when oocytes reach the dictyate stage (P1-P2), Cdk2 mutant oocytes display multiple defects (desynapsed fibers, randomly distributed centromeres, etc.) which indicate that $C d \mathrm{k}^{-/-}$oocytes also have a defect in prophase I, albeit at a later developmental stage (Ortega et al. 2003). These observations establish that Cdk2 is essential for completion of the first meiotic division in both male and female germ cells.

Interestingly, mice deficient for both E-type cyclins are not viable, most likely due to a defect in the endoreplication of placental trophoblast giant cells (Geng et al. 2003; Parisi et al. 2003). These observations provide genetic evidence for a differential role of Cdk2 and E-type cyclins, at least during endoreplication. This suggests that E-type cyclins must have a partner(s) other than Cdk2. Whether such partners are Cdks, and whether they are functional in cells other than trophoblasts, remain to be determined.

\section{Cdk2 IS DISPENSABLE FOR THE MITOTIC CELL CYCLE}

Primary $C d k 2^{--}$MEFs grow well in culture and proliferate with kinetics similar to those of wild-type cells (Berthet et al. 2003; Ortega et al. 2003). Serum-starved $C d k 2^{-1-}$ MEFs enter $\mathrm{S}$ phase with the same kinetics as their wild-type counterparts upon serum stimulation. $C d k 2^{-1-}$ MEFs also become immortalized upon continuous passage in culture. Indeed, we have only observed subtle differences in the timing at which these cells enter culture crisis. Moreover, removal of $\mathrm{Cdk} 2$ from $C d k 2^{\operatorname{lox} /-}$ MEFs does not have significant consequences in their proliferative properties, indicating that $\mathrm{Cdk} 2$ is dispensable for cell proliferation in conditions in which plasticity is unlikely to play a role (Ortega et al. 2003). E-type cyclin-deficient MEFs also proliferate well in culture. However, these cells have a defect in cell cycle re-entry, presumably due to a failure in loading MCM proteins onto DNA replication origins (Geng et al. 2003). These observations provide additional genetic evidence for the existence of E-type cyclin partners other than Cdk2. Whether the putative cyclin E partners responsible for this cell cycle defect are the same as those required for endoreplication remains to be determined.

\section{ABSENCE OF SYNERGISM BETWEEN Cdk6 AND Cdk2 DEFICIENCIES}

Crosses between $\mathrm{CdkO}^{+/-} ; \mathrm{Cdk2}^{+/-}$heterozygous mice yield $C d k 6^{-1-} ; C d k 2^{-/-}$double null animals with expected Mendelian ratios. Mice defective for Cdk6 and Cdk2 display those phenotypical abnormalities previously observed in Cdk6 and Cdk2 single mutant strains (Ortega et al. 2003; Malumbres et al. 2004). Briefly, $C d k 6^{-1-} ; C d k 2^{-1-}$ animals are sterile and show marked defects in spermatogenesis and oogenesis, basically indistinguishable from those reported for Cdk2-deficient mice (Ortega et al. 2003). They also have limited defects in hematopoietic cells similar to those described above for Cdk6 null mice. Finally, $C d k 6^{-1-} ; C d k 2^{---}$animals survive for up to 1.5 years without developing obvious additional abnormalities (Malumbres et al. 2004).

\section{Cdk2 IS ALSO DISPENSABLE FOR CELL CYCLE REGULATION MEDIATED BY Cip/Kip INHIBITORS}

The above results challenge the central roles attributed to Cdk2 in cell cycle progression. One such role involves mediating the inhibitory properties and tumor-suppress- 
ing activities of $\mathrm{p} 21^{\mathrm{Cip} 1}$ and $\mathrm{p} 27^{\mathrm{Kip} 1}$, the best characterized members of the Cip/Kip family of cell cycle inhibitors (Sherr and Roberts 1999). Infection of primary MEFs with retroviruses expressing $\mathrm{p} 21^{\mathrm{Cip} 1}$ or $\mathrm{p} 27^{\mathrm{Kip} 1}$ proteins halts their proliferation regardless of the presence or absence of Cdk2 (Martín et al. 2005). About half of the $C d k 2^{--}$MEFs are halted in $\mathrm{G}_{2} / \mathrm{M}$, a result likely due to inhibition of Cdk1. However, most $C d k 2^{-1-}$ cells $(60 \%)$ are arrested in $\mathrm{G}_{1}$. Genetic evidence argues against a compensatory role of $\mathrm{Cdk} 4$ and $\mathrm{Cdk} 6$, since $\mathrm{p} 27^{\mathrm{Kip} 1}$ and p2 $1^{\text {Cip1 }}$ effectively block cell proliferation in MEFs lacking either Cdk4 and Cdk6, or the three D-type cyclins (Kozar et al. 2004; Malumbres et al. 2004). Generation of double $\mathrm{Cdk} 2 / \mathrm{Cdk} 4$ mutant cells or cells lacking the three $\mathrm{G}_{1} / \mathrm{S}$ Cdks: Cdk2, Cdk4, and Cdk6, should help to decipher the functional target(s) of the Cip/Kip inhibitors.

Primary $p 27^{\text {Kip } 1-/-} ; C d k 2^{-/-}$and $p 21^{\text {Cip } 1-/-} ; C d k 2^{-/-}$ MEFs display increased proliferation rates similar to those of $p 27^{\text {Kip } 1}$ null or $p 21^{\text {Cipl }}$ null cells (Martín et al. 2005). These observations indicate that loss of Cdk2 does not abrogate the proliferative advantage conferred by the absence of p $27^{K i p 1}$ or p21 ${ }^{\text {Cipl } 1}$ tumor suppressors. Moreover, quiescent $p 27^{\text {Kip } 1-1-_{1}} ; C d k 2^{-1-}$ and $p 21^{\text {Cip } 1-1-_{C}} ; C d k 2^{-1-}$ MEFs enter S phase 4-6 hours earlier than wild-type cells upon serum stimulation (Martín et al. 2005), indicating that the shortening in $\mathrm{S}$ phase entry cannot be mediated by constitutive activation of $\mathrm{Cdk} 2$.

\section{Cdk2 IS NOT ESSENTIAL FOR p21 ${ }^{\text {Cip1-MEDIATED CELL CYCLE ARREST }}$ AFTER DNA DAMAGE}

$\mathrm{p} 21^{\mathrm{Cip} 1}$ is one of the major effectors of cell cycle arrest induced following DNA damage. Double mutant $p 21^{\text {Cip1-/- }} ; \mathrm{Cdk2}^{-/-}$cells display the same levels of BrdU incorporation as $p 21^{\mathrm{Cip} 1-1-}$ MEFs upon exposure to gamma radiation or to etoposide treatment. Moreover, these double mutant cells also fail to arrest in $G_{1}$ after these treatments (Martín et al. 2005). These observations provide genetic evidence against the concept that $\mathrm{p} 21^{\mathrm{Cip} 1}$ mediates cell cycle arrest at the DNA damage checkpoint by blocking Cdk2 activity.

\section{THE TUMOR SUPPRESSOR ACTIVITY OF p2 $7^{\text {Kip1 }}$ DOES NOT REQUIRE Cdk2}

Mice defective for $\mathrm{p} 27^{\mathrm{Kip} 1}$ are bigger in size, display organomegaly and retinal defects, and develop frequent pituitary tumors (Fero et al. 1996; Kiyokawa et al. 1996; Nakayama et al. 1996). $p 27^{\text {Kip } 1-1-} ; C d k 2^{-1-}$ double mutant mice weigh, on average, $50-60 \%$ more than wild type and display widespread organomegaly similar to p27 $7^{\text {Kip1-l- }}$ null animals, except in testis and ovaries which were as hypotrophic as in $C d k 2^{-1-}$ mice (Martín et al. 2005). $p 27^{\text {Kip } 1-/-} ; C d k 2^{-1-}$ mutant animals display the same retinal defects observed in $p 27^{\text {Kip } 1}$ null mice and with similar penetrance (about 10\%) (Kiyokawa et al. 1996; Nakayama et al. 1996). More importantly, these double mutant mice develop pituitary tumors with the same high penetrance and latency as p2 $7^{\mathrm{Kip} 1}$ single mu- tant animals (Martín et al. 2005). The pituitary tumors of p2 $7^{\text {Kip } 1-1-} ; C d k 2^{-1-}$ mice display the same elevated proliferative indexes and volume sizes as those observed in p2 $7^{\text {Kip 1-/- }}$ null mice. These results illustrate that Cdk2 is not required to mediate the in vivo tumor suppressor activity of $\mathrm{p} 27^{\mathrm{Kip} 1}$.

\section{CONCLUSIONS}

\section{Cell Cycle Mutations and Cancer}

Cancer is frequently considered as a cell cycle disease. Although many cell cycle regulatory mechanisms have been studied at length in vitro, it is still unclear how they are coordinately regulated in vivo and how their misregulation leads to human cancer. Evidence accumulated over the last decade has clearly illustrated that mutation of the same cell cycle regulators known to be mutated or epigenetically altered in human cancer also leads to tumor development in mice (Ortega et al. 2002). For instance, $p R b^{+/-}$(Jacks et al. 1992; Lee et al. 1992), $C d k 4^{\mathrm{R} 24 \mathrm{C} / \mathrm{R} 24 \mathrm{C}}$ (Rane et al. 1999; Sotillo et al. 2001a), and Ink4a/Arf ${ }^{-1}$ (Serrano et al. 1996) mice develop tumors with complete penetrance. Other mutations, such as those ablating the INK4 inhibitors $\mathrm{p} 16^{\text {Ink4a }}$ and $\mathrm{p} 15^{\text {Ink } 4 \mathrm{~b}}$, have not led to overt tumor development (Latres et al. 2000; Krimpenfort et al. 2001; Sharpless et al. 2001) but seem to predispose to cancer. Whether these mutations in humans only contribute to carcinogenesis in the presence of other mutations remains to be determined. Finally, amplification of cyclin D1 or cyclin E in mice also leads to abnormal growth, albeit not to overt tumor growth, suggesting that they are contributors, but not "primary drivers" of carcinogenesis.

\section{Cdks and the Regulation of the Cell Cycle}

Genetic analysis of the role of Cdks has provided a series of observations that are not compatible with widely accepted models for the mammalian cell cycle. Mainly, neither the D-type cyclins nor their cognate cyclin D-dependent kinases, Cdk4 and Cdk6, are essential for cell proliferation or exit from quiescence in most cell types. Only cells of hematopoietic origin appear to require at least one of these D-type cyclins or their kinase partners for proper proliferation. Several issues need to be addressed before we can fully evaluate the requirements for the D-type cyclin-dependent kinases in mammalian cells. For instance, we need to determine whether they are required in adult tissues, since it could be argued that during embryonic development most cells do not exit the cycle. Alternatively, it is possible that exit from quiescence during embryogenesis might be regulated by mechanisms distinct from those that regulate cell cycle re-entry in adult cells.

It is also possible that in the absence of Cdk4 and Cdk6, cellular plasticity allows Cdk2 to interact with the D-type cyclins and to compensate for their absence. Likewise, it could be argued that the Cdk2/cyclin E kinases may functionally compensate for the lack of D-cyclin-dependent 
kinase activity (Geng et al. 1999). Generation of triple Cdk4/Cdk6/Cdk2 null mice should help to resolve some of these issues.

Regardless of potential compensatory effects by other Cdks, or even by other less related kinases, the absolute dispensability of Cdk2 in mitotic cells in vivo is an unexpected finding. Despite extensive bibliography linking $\mathrm{Cdk} 2$ to many critical cellular processes such as DNA replication and centrosome duplication (Sherr and Roberts 1999), available genetic evidence to date has failed to demonstrate a role for Cdk2 in these processes. Equally surprising have been recent genetic observations indicating that $\mathrm{Cdk} 2$ is not essential for mediating the cell cycle inhibitory properties of the Cip/Kip inhibitors p $21^{\text {Cip } 1}$ and p2 $7^{\text {Kip1 }}$ (Aleem et al. 2005; Martín et al. 2005). Likewise, the presence or absence of $\mathrm{Cdk} 2$ has no effect on the incidence or latency of pituitary tumors caused by loss of $\mathrm{p} 27^{\mathrm{Kip} 1}$. These observations have direct implications in the design of therapeutic strategies to fight tumors in which there is loss of $\mathrm{p} 27^{\mathrm{Kip} 1}$ expression, or even loss of $\mathrm{P} 53$, since this tumor suppressor controls the synthesis of $\mathrm{p} 21^{\text {Cip } 1}$. Although the essential targets for $\mathrm{p} 21^{\mathrm{Cip} 1}$ and $\mathrm{p} 27^{\mathrm{Kip} 1}$ tumor suppressors remain to be identified, it is likely that they block cell cycle progression, at least partially, by inhibiting Cdk1. Whether inhibition of Cdk1 will have a selective effect on tumor cells is a key issue that should be addressed by genetic means before selective inhibitors are developed.

In summary, our results illustrate the need to continue interrogating the cell cycle by genetic means. An integrated view from biochemical studies, experimental animal models, and the analysis of cancer mutations will undoubtedly help to exploit this knowledge to develop rational therapeutic approaches with which to target those tumors exhibiting a deregulated cell cycle.

\section{REFERENCES}

Aleem E., Kiyokawa H., and Kaldis P. 2005. Cdc2-cyclin E complexes regulate the G1/S phase transition. Nat. Cell Biol. 7: 831.

Berthet C., Aleem E., Coppola V., Tessarollo L., and Kaldis P. 2003. Cdk2 knockout mice are viable. Curr. Biol. 13: 1775.

Ciemerych M.A. and Sicinski P. 2005. Cell cycle in mouse development. Oncogene 24: 2877.

Classon M. and Harlow E. 2002. The retinoblastoma tumour suppressor in development and cancer. Nat. Rev. Cancer 2: 910.

Cobrinik D. 2005. Pocket proteins and cell cycle control. Oncogene 24: 2796.

Esteller M. 2005. Aberrant DNA methylation as a cancer-inducing mechanism. Annu. Rev. Pharmacol. Toxicol. 45: 629.

Fero M.L., Rivkin M., Tasch M., Porter P., Carow C.E., Firpo E., Polyak K., Tsai L.H., Broudy V., Perlmutter R.M., Kaushansky K., and Roberts J.M. 1996. A syndrome of multiorgan hyperplasia with features of gigantism, tumorigenesis, and female sterility in p27( $\left.{ }^{\mathrm{Kip} 1}\right)$-deficient mice. Cell 85: 733.

Geng Y., Whoriskey W., Park M.Y., Bronson R.T., Medema R.H., Li T., Weinberg R.A., and Sicinski P. 1999. Rescue of cyclin D1 deficiency by knockin cyclin E. Cell 97: 767.

Due to space limitations we could not include all the appropriate references. The reader is referred to the reviewed articles for specific references.
Geng Y., Yu Q., Sicinska E., Das M., Schneider J.E., Bhattacharya S., Rideout W.M., Bronson R.T., Gardner H., and Sicinski P. 2003. Cyclin E ablation in the mouse. Cell 114: 431.

Jacks T., Fazeli A., Schmitt E.M., Bronson R.T., Goodell M.A., and Weinberg R.A. 1992. Effects of an Rb mutation in the mouse. Nature 359: 295.

Jirawatnotai S., Aziyu A., Osmundson E.C., Moons D.S., Zou X., Kineman R.D., and Kiyokawa H. 2004. Cdk4 is indispensable for postnatal proliferation of the anterior pituitary. $J$. Biol. Chem. 279: 51100.

Kiyokawa H., Kineman R.D., Manova-Todorova K.O., Soares V.C., Hoffman E.S., Ono M., Khanam D., Hayday A.C., Frohman L.A., and Koff A. 1996. Enhanced growth of mice lacking the cyclin-dependent kinase inhibitor function of p27(Kip1). Cell 85: 721.

Kozar K., Ciemerych M.A., Rebel V.I., Shigematsu H., Zagozdzon A., Sicinska E., Geng Y., Yu Q., Bhattacharya S., Bronson R.T., Akashi K., and Sicinski P. 2004. Mouse development and cell proliferation in the absence of D-cyclins. Cell 118: 477.

Krimpenfort P., Quon K.C., Mooi W.J., Loonstra A., and Berns A. 2001. Loss of p16Ink4a confers susceptibility to metastatic melanoma in mice. Nature 413: 83.

Latres E., Malumbres M., Sotillo R., Martín J., Ortega S., Martín-Caballero J., Flores J.M., Cordon-Cardo C., and Barbacid M. 2000. Limited overlapping roles of P15(INK4b) and $\mathrm{P} 18$ (INK4c) cell cycle inhibitors in proliferation and tumorigenesis. EMBO J. 19: 3496.

Lee E.Y., Chang C.Y., Hu N., Wang Y.C., Lai C.C., Herrup K., Lee W.H., and Bradley A. 1992. Mice deficient for Rb are nonviable and show defects in neurogenesis and haematopoiesis. Nature 359: 288.

Malumbres M. and Barbacid M. 2001. To cycle or not to cycle: A critical decision in cancer. Nat. Rev. Cancer 1: 222.

Malumbres M., Sotillo R., Santamaria D., Galan J., Cerezo A., Ortega S., Dubus P., and Barbacid M. 2004. Mammalian cells cycle without the D-type cyclin-dependent kinases Cdk4 and Cdk6. Cell 118: 493.

Martín J., Hunt S.L., Dubus P., Sotillo R., Nehme-Pelluard F., Magnuson M.A., Parlow A.F., Malumbres M., Ortega S., and Barbacid M. 2003. Genetic rescue of Cdk4 null mice restores pancreatic beta-cell proliferation but not homeostatic cell number. Oncogene 22: 5261.

Martín A., Odajima J., Hunt S.L., Dubus P., Ortega S., Malumbres M., and Barbacid M. 2005. Cdk2 is dispensable for cell cycle inhibition and tumor suppression mediated by $\mathrm{p} 27^{\mathrm{Kip} 1}$ and $\mathrm{p} 21^{\text {Cip1 } 1 . ~ C a n c e r ~ C e l l ~ 7: ~} 591$.

Moons D.S., Jirawatnotai S., Tsutsui T., Franks R., Parlow A.F., Hales D.B., Gibori G., Fazleabas A.T., and Kiyokawa H. 2002. Intact follicular maturation and defective luteal function in mice deficient for cyclin-dependent kinase-4. Endocrinology 143: 647.

Nakayama K., Ishida N., Shirane M., Inomata A., Inoue T., Shishido N., Horii I., Loh D.Y., and Nakayama K. 1996. Mice lacking p27( $\left.{ }^{\mathrm{Kip} 1}\right)$ display increased body size, multiple organ hyperplasia, retinal dysplasia, and pituitary tumors. Cell 85: 707.

Ortega S., Malumbres M., and Barbacid M. 2002. Cyclin D-dependent kinases, INK4 inhibitors and cancer. Biochim. Biophys. Acta 1602: 73.

Ortega S., Prieto I., Odajima J., Martín A., Dubus P., Sotillo R., Barbero J.L., Malumbres M., and Barbacid M. 2003. Cyclindependent kinase 2 is essential for meiosis but not for mitotic cell division in mice. Nat. Genet. 35: 25.

Paggi M.G. and Giordano A. 2001. Who is the boss in the retinoblastoma family? The point of view of $\mathrm{Rb} 2 / \mathrm{p} 130$, the little brother. Cancer Res. 61: 4651.

Parisi T., Beck A.R., Rougier N., McNeil T., Lucian L., Werb Z., and Amati B. 2003. Cyclins E1 and E2 are required for endoreplication in placental trophoblast giant cells. EMBO J. 22: 4794.

Rane S.G., Dubus P., Mettus R.V., Galbreath E.J., Boden G., Reddy E.P., and Barbacid M. 1999. Loss of Cdk4 expression 


\section{BARBACID ET AL.}

causes insulin-deficient diabetes and Cdk4 activation results in $\beta$-cell hyperplasia. Nat. Genet. 22: 44.

Ren S. and Rollins B.J. 2004. Cyclin C/cdk3 promotes Rb-dependent G0 exit. Cell 117: 239

Serrano M., Lee H., Chin L., Cordon-Cardo C., Beach D., and DePinho R.A. 1996. Role of the INK4a locus in tumor suppression and cell mortality. Cell 85: 27 .

Sharpless N.E., Bardeesy N., Lee K.H., Carrasco D., Castrillon D.H., Aguirre A.J., Wu E.A., Horner J.W., and DePinho R.A. 2001. Loss of p16Ink4a with retention of p19Arf predisposes mice to tumorigenesis. Nature 413: 86 .

Sherr C.J. and Roberts J.M. 1999. CDK inhibitors: Positive and negative regulators of G1-phase progression. Genes Dev. 13: 1501

Sotillo S., Dubus P., Martín J., de la Cueva E., Ortega S.,
Malumbres M., and Barbacid M. 2001a. Wide spectrum of tumors in knock in mice carrying a Cdk4 protein insensitive to INK4 inhibitors. EMBO J. 20: 6637.

Sotillo R., García J.F., Ortega S., Martín J., Dubus P., Barbacid M., and Malumbres M. 2001b. Invasive melanoma in Cdk4 targeted mice. Proc. Natl. Acad. Sci. 98: 13312.

Tsutsui T., Hesabi B., Moons D.S., Pandolfi P.P., Hansel K.S. Koff A., and Kiyokawa H. 1999. Targeted disruption of Cdk4 delays cell cycle entry with enhanced p27Kip1 activity. Mol. Cell. Biol. 19: 7011.

Yamasaki L. and Pagano M. 2004. Cell cycle, proteolysis and cancer. Curr. Opin. Cell. Biol. 16: 623.

Ye X., Zhu C., and Harper J.W. 2001. A premature-termination mutation in the Mus musculus cyclin-dependent kinase 3 gene. Proc. Natl. Acad. Sci. 98: 1682. 


\section{$\$_{\text {SSH\& }}^{\infty} \mathrm{CS}$ Cold Spring Harbor Symposia SYMPOSIA on Quantitative Biology}

\section{Cell Cycle and Cancer: Genetic Analysis of the Role of Cyclin-dependent Kinases}

M. BARBACID, S. ORTEGA, R. SOTILLO, et al.

Cold Spring Harb Symp Quant Biol 2005 70: 233-240

Access the most recent version at doi:10.1101/sqb.2005.70.005

References This article cites 36 articles, 9 of which can be accessed free at:

http://symposium.cshlp.org/content/70/233.full.html\#ref-list-1

License

Email Alerting Receive free email alerts when new articles cite this article - sign up in

Service the box at the top right corner of the article or click here. 